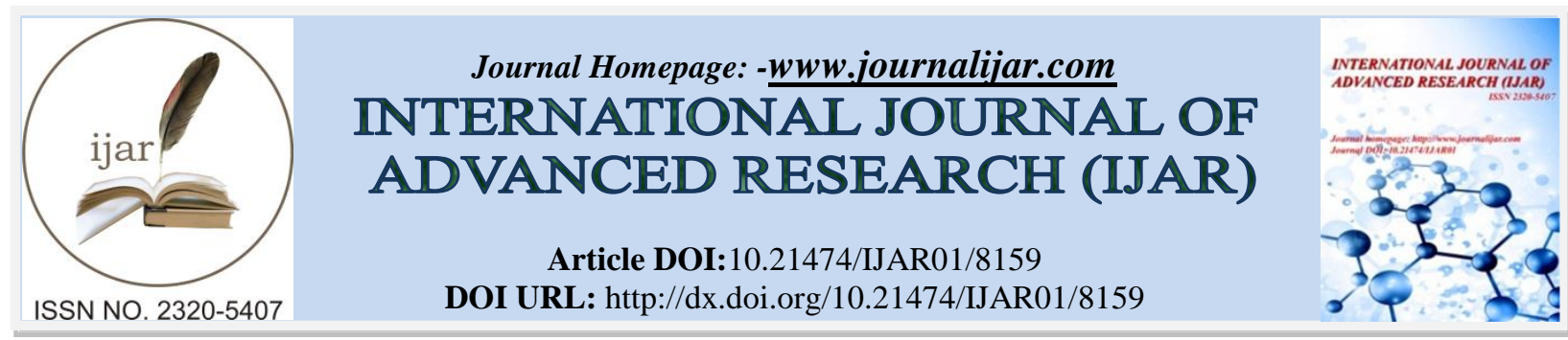

RESEARCH ARTICLE

\title{
ENUMERATION OF BACTERIA; A TOOL FOR WATER QUALITY EVALUATION IN TUNGA RESERVOIR AT GAJANUR, KARNATAKA.
}

\section{S.Prathibha ${ }^{1}$ and V.N.Murulidhar ${ }^{2}$.}

1. Department of Botany, JSS College of Arts, Commerce and Science [Autonomous], Ooty Road, Mysore570025, Karnataka.

2. Department of Botany, Government First Grade College of Arts, Science and Commerce, Sira-572137, Karnataka.

\section{Manuscript Info}

\section{Manuscript History}

Received: 04 October 2018

Final Accepted: 06 November 2018

Published: December 2018

Keywords:-

Reservoir, Potability, Coliforms,

Streptococci

\section{Abstract}

Aquatic bacteria forms most dangerous constituents of potable water and play a vital role in causing enteric disorders, thus bacteriological examination of potable water is therefore a greater importance from the public health point of view. Sometimes bacteria also act as indicator organisms for the characterization of condition of potable water. Primary objective of bacteriological examination of water is the detection of faecal pollution. Many instances have occurred, where reported chemical analysis of water supply has failed to reveal any evidence of pollution which never the less existed and was well demonstrated by bacteriological methods. The present study was conducted by collecting water samples on monthly basis from Tunga reservoir at Gajanur. The reservoir receives agricultural runoff during monsoon from the upstream water. Results of the present study revealed that the water is bacteriologically contaminated and contains faecal coli forms and faecal streptococci above the permissible limits for potability. Mean values of different types of bacteria along with seasonal variations was also worked out and has been discussed in detail. Immediate remedial measures have also been suggested.

Copy Right, IJAR, 2018,. All rights reserved.

\section{Introduction:-}

Aquatic bacteria play a vital role in carrying water borne diseases, which cause epidemics. These pathogenic bacteria enter in to water through external pollutants mostly by domestic contaminants such as human and animal excreta. Hence, importance of microbial analysis of water has been emphasised from time and again. Bacteria are the causative agents of many enteric disorders which indicate much more level of delicate pollution. Since the discovery and methods of identifying different groups of bacteria form the most dangerous constituents of potable water. Thus the bacteriological examination of potable water is therefore of greater importance from the public health point of view. Besides the physical and chemical parameters, biological ones have also been utilised for a long time for the 
evaluation of water quality in inland and coastal waters. Kolkwitz and Marsson (1908) used bacteria besides other animal creatures as indicator organisms for the characterization of water condition and also suggested various bacteria for the individual saprobic stages. Primary objective of bacteriological examination of water is the detection of faecal pollution. The danger of polluted water comes from living organisms and not from dead organic matter. Large number of bacteria may be found in water of the highest standard of organic purity. Many instances have occurred where, reported chemical analysis of water supply has failed to reveal any evidence of pollution which never the less existed and was well demonstrated by bacteriological methods. Bacteriological analysis may be depended upon to detect a much smaller quantity of polluting matter. The opinion should not be expressed on the purity of water, however good the results of the chemical analysis, without a knowledge of its bacteriology. Bacteriological investigation is the most sensitive means of detecting faecal contamination and therefore, potentially dangerous pollution (Anon, 1982).

\section{Study Area:-}

The river Tunga originates at Gangamoola in the Varaha parvata at an elevation of about 1,199 meter high in the Agumbe range of Western Ghats in Chikkamagalore district of Karnataka state. River Tunga flows to an extent of $130 \mathrm{kms}$ in Sringeri and Koppa taluks of Chikkamagalore district and Tirtahalli and Shimogga taluks of Shimogga district is an important tributary of river Tungabhadra. River Tunga with a catchment area of 2239 square kilometres is a perennial river. The abundance of water during June to October offsets the balance of water for all irrigation wells along the length of the river and prompted it as the chief source of drinking water. Dam has been built across the river Tunga near Gajanur at a distance of 14.5 kilometer from Shimogga city between $13^{0} 15^{\mathrm{I}}$ North latitude and $75^{0} 31^{\mathrm{I}}$ East longitude.

Upstream of Gajanur reservoir, an apparently pollutant non discharge area receives only natural runoff. This was considered as a sampling station to study the ecological changes which take place during the conversion of water in to water body of slow discharge characteristics. The flow of the river brings lot of materials that get decayed in the storage phase. The water of the reservoir is being used for agricultural operations and also as a source of drinking water. Marginal emergent plants such as Marsilea quadrifolia, Cyperus rotundus, Polygonum hydropiper and Ipomea aquatica are found growing along the margins. Since the river spreads epidemics of enteric diseases in the area around, there seem to be an urgent need of bacteriological investigation, so that curative measures could be taken to protect the health of rural people from the water borne diseases.

\section{Methodology:-}

Surface water samples were collected from April 2016 to March 2017 on monthly basis for the analysis of physicochemical and bacteriological parameters. Standard methods APHA (2005) and guidelines of WHO (1998) were followed for the analysis of physico-chemical and bacteriological parameters. Temperature of air and water and $\mathrm{PH}$ were recorded on the spot at the time of collection of water samples. For the enumeration of dissolved oxygen the water samples were fixed in $300 \mathrm{ml}$ BOD bottles using Winkler's reagent at the time of collection. The samples were labelled and transported in an ice box to the laboratory for the analysis of various physico-chemical parameters.

For the evaluation of bacteria, samples were collected in polypropylene autoclavable plastic bottles of $300 \mathrm{ml}$ capacity; sterilised by autoclaving at $121^{\circ} \mathrm{C}$ for 15 minutes, the neck and the lid being covered by double layered aluminium foil. The samples were collected at a depth of 1 foot below the surface against the water current. After insertion of the lid on the neck of the bottle and proper labelling the samples were transported immediately at $40{ }^{\circ} \mathrm{C}$ in an ice box and examined within 6 hours of collection following the methods of APHA (1995). 
Table-1:-Range and Mean Values of Physico-Chemical Parameters

\begin{tabular}{|c|c|c|c|c|c|c|}
\hline SL NO & PARAMETERS & MEAN & STD DEV & STD ERR & MIN & MAX \\
\hline 1 & P1 & 28.7708 & 4.4134 & 0.9009 & 22.00 & 35.00 \\
\hline 2 & P2 & 27.7292 & 4.4355 & 0.9054 & 21.00 & 34.00 \\
\hline 3 & P3 & 107.4583 & 18.2923 & 3.7339 & 65.00 & 131.00 \\
\hline 4 & P4 & 6.9042 & 0.3617 & $7.384 \mathrm{E}-2$ & 6.30 & 8.00 \\
\hline 5 & P5 & 90.7763 & 13.8329 & 2.8236 & 70.00 & 112.00 \\
\hline 6 & P6 & 88.6688 & 14.4703 & 2.9537 & 72.00 & 120.00 \\
\hline 7 & P7 & 46.9021 & 9.0341 & 1.8441 & 28.30 & 65.00 \\
\hline 8 & P8 & 52.2258 & 7.0840 & 1.4460 & 43.20 & 68.00 \\
\hline 9 & P9 & 204.8708 & 20.4868 & 4.1819 & 165.00 & 240.00 \\
\hline 10 & P10 & 20.9950 & 2.3913 & 0.4881 & 18.00 & 26.50 \\
\hline 11 & P11 & 18.4791 & 4.7198 & 0.9634 & 8.50 & 24.00 \\
\hline 12 & P12 & 54.6392 & 10.7973 & 2.2040 & 42.00 & 78.00 \\
\hline 13 & P13 & 7.1208 & 0.4782 & $9.761 \mathrm{E}-2$ & 6.30 & 8.00 \\
\hline 14 & P14 & 10.9667 & 5.0342 & 1.0276 & 3.50 & 18.00 \\
\hline 15 & P15 & $3.183 \mathrm{E}-2$ & $1.986 \mathrm{E}-2$ & $4.054 \mathrm{E}-3$ & 0.01 & 0.10 \\
\hline
\end{tabular}

P1 - Air Temperature, P2 - Water Temperature, P 3 - Turbidity, P4 - PH, P5 - Electrical Conductivity, P6 - Total Solids, P7 - Dissolved Solids, P8 - Chloride, P9 - Sulphate, P10-Calcium, P11 - Magnesium, P12 - Total Hardness, P13 - Dissolved Oxygen, P14 - BOD, P15 - Phosphate, STD DEV - Standard Deviation, STD ERR - Standard Error, MIN - Minimum, MAX - Maximum

Table-2:-Seasonal Variation of Mean and Standard Deviation of Physico-Chemical Parameters

\begin{tabular}{|c|c|c|c|c|c|c|c|}
\hline \multirow{2}{*}{$\begin{array}{c}\text { SL. } \\
\text { NO. }\end{array}$} & \multirow{2}{*}{ PARAMETERS } & \multicolumn{2}{|c|}{ SUMMER } & \multicolumn{2}{c|}{ RAINY } & \multicolumn{2}{c|}{ WINTER } \\
\cline { 2 - 7 } & MEAN & STD DEV & MEAN & STD DEV & MEAN & STD DEV \\
\hline 1 & P1 & 33.38 & 1.92 & 24.13 & 2.03 & 28.81 & 2.70 \\
\hline 2 & P2 & 32.38 & 1.92 & 23.00 & 1.85 & 27.81 & 2.70 \\
\hline 3 & P3 & 113.63 & 17.98 & 100.25 & 19.71 & 108.50 & 16.84 \\
\hline 4 & P4 & 6.71 & 0.32 & 7.15 & 0.37 & 6.85 & 0.27 \\
\hline 5 & P5 & 88.94 & 17.13 & 99.05 & 6.12 & 84.34 & 12.97 \\
\hline 6 & P6 & 93.38 & 21.50 & 86.84 & 5.73 & 85.79 & 12.43 \\
\hline 7 & P7 & 49.88 & 4.91 & 45.41 & 11.60 & 45.43 & 9.71 \\
\hline 8 & P8 & 55.28 & 9.42 & 51.63 & 3.53 & 49.78 & 6.76 \\
\hline 9 & P9 & 189.36 & 16.53 & 221.79 & 12.72 & 203.46 & 18.43 \\
\hline 10 & P10 & 20.38 & 1.75 & 21.41 & 2.20 & 21.20 & 3.19 \\
\hline 11 & P11 & 21.75 & 1.28 & 16.04 & 6.52 & 17.65 & 3.03 \\
\hline 12 & P12 & 56.38 & 15.45 & 51.05 & 5.53 & 56.50 & 9.58 \\
\hline 13 & P13 & 7.15 & 0.35 & 7.52 & 0.53 & 6.96 & 0.54 \\
\hline 14 & P14 & 7.15 & 0.35 & 7.52 & 0.53 & 6.96 & 0.54 \\
\hline 15 & P15 & 0.03 & 0.01 & 0.04 & 0.02 & 0.02 & 0.01 \\
\hline
\end{tabular}

P1 - Air Temperature, P2 - Water Temperature, P 3 - Turbidity, P4 - PH, P5 - Electrical Conductivity, P6 - Total Solids, P7 - Dissolved Solids, P8 - Chloride, P9 - Sulphate, P10-Calcium, P11 - Magnesium, P12 - Total Hardness, P13 - Dissolved Oxygen, P14 - BOD, P15 - Phosphate, STD DEV - Standard Deviation 
Table-3:-Range and Mean Values of Different Types of Bacteria

\begin{tabular}{|c|c|c|c|c|c|c|}
\hline SL NO & BACTERIA & MEAN & STD DEV & STD ERR & MIN & MAX \\
\hline 1 & $\begin{array}{c}\text { Faecal Coliforms } \\
\text { FC / 100ml }\end{array}$ & 1247.0833 & 1985.9539 & 405.3811 & 110.00 & 9200.00 \\
\hline 2 & $\begin{array}{c}\text { Faecal Streptococci } \\
\text { FS / 100ml }\end{array}$ & 222.2083 & 157.1322 & 32.0745 & 17.00 & 540.00 \\
\hline
\end{tabular}

Table 4:-Seasonal Variation of Different Types of Bacteria

\begin{tabular}{|c|l|c|c|c|c|c|c|}
\hline \multirow{2}{*}{$\begin{array}{l}\text { SL } \\
\text { NO }\end{array}$} & \multirow{2}{*}{ BACTERIA } & \multicolumn{2}{|c|}{ SUMMER } & \multicolumn{2}{c|}{ RAINY } & \multicolumn{2}{c|}{ WINTER } \\
\cline { 3 - 7 } & MEAN & STD DEV & MEAN & STD DEV & MEAN & STD DEV \\
\hline 1 & $\begin{array}{l}\text { Faecal Coli forms } \\
\text { FC / } 100 \mathrm{ml}\end{array}$ & $8.9 \times 10^{2}$ & $1.16 \times 10^{3}$ & $2.36 \times 10^{3}$ & $3.03 \times 10^{3}$ & $4.91 \times 10^{2}$ & $4.42 \times 10^{2}$ \\
\hline 2 & $\begin{array}{l}\text { Faecal Streptococci } \\
\text { FS } / 100 \mathrm{ml}\end{array}$ & $2.21 \times 10^{2}$ & $1.62 \times 10^{2}$ & $2.08 \times 10^{2}$ & $2.24 \times 10^{2}$ & $2.4 \times 10^{2}$ & $6.1 \times 10^{1}$ \\
\hline
\end{tabular}

Photographs:-

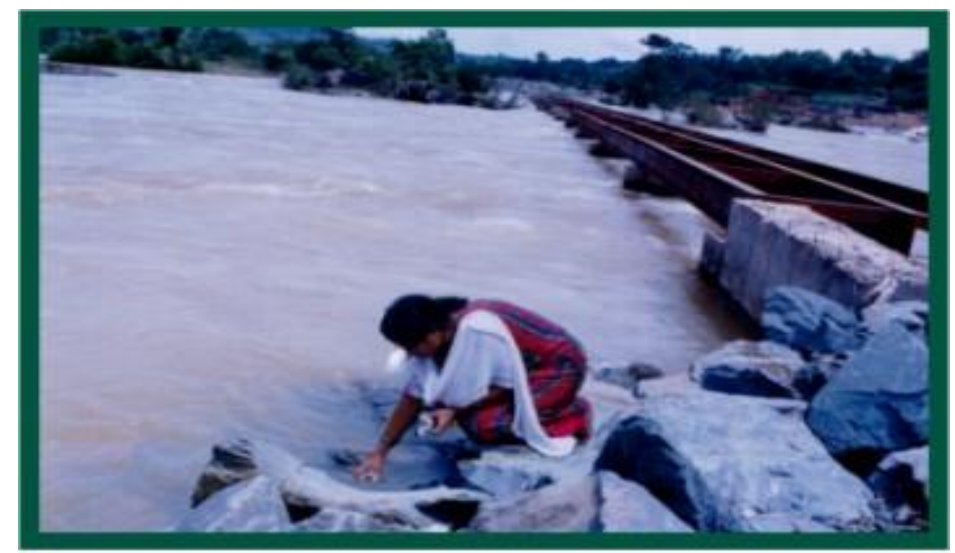

\section{Sampling during rainy season}

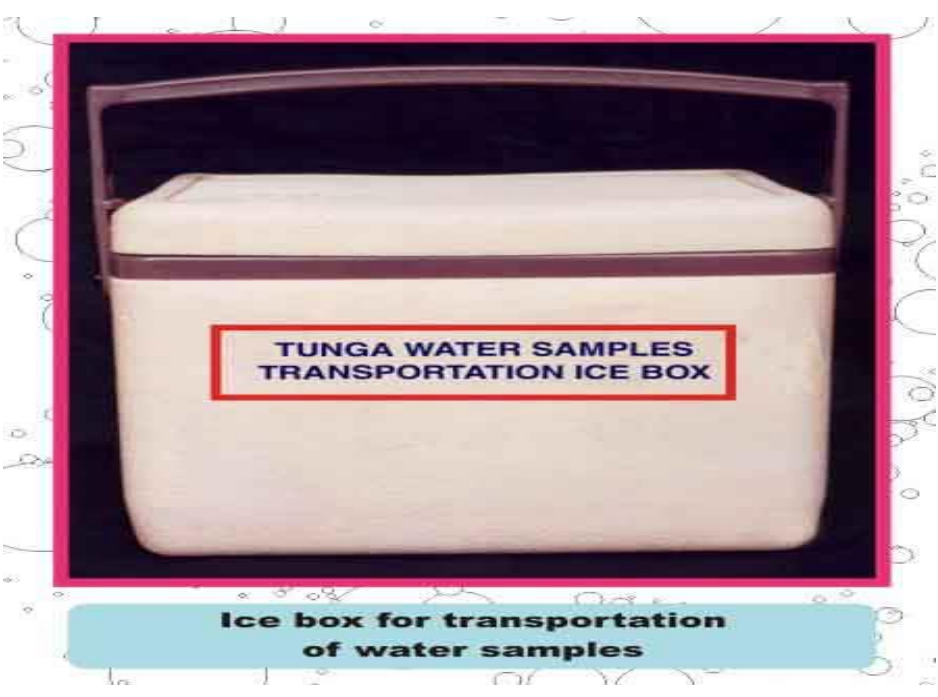




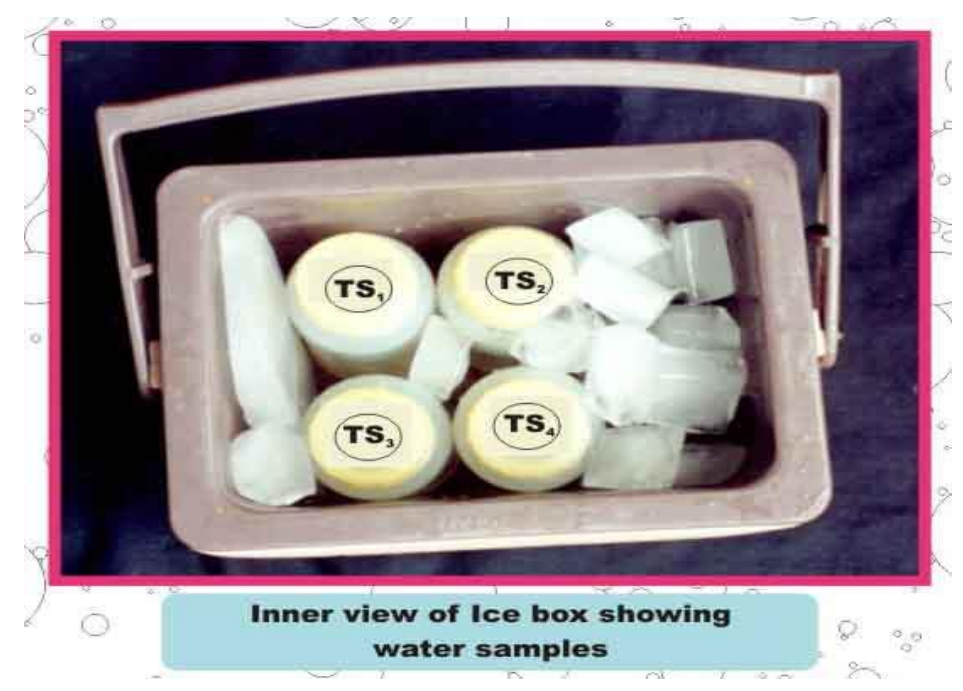

\section{Results And Discussion:-}

Range, mean, standard deviation and standard error of physico-chemical parameters are represented in table-1. Seasonal variation of physico-chemical parameters is given in table-2. As revealed in the table, air temperature showed higher summer averages with rainy minima. Contrary to our findings low winter averages were recorded by Manjappa (2001) and Vanaja (1998). Water temperature is found to be under direct influence of air temperature. Parvateesam and Sudha Gupta (1992) observed higher water temperature during summer and minimum during rainy which may be due to greater heating and insolent heat from the Sun. Similar observations have been made during the present investigation also. Highest values of turbidity observed during summer is mainly due to the decrease in the volume of river water coupled with the increased load of suspended solids, which is supported by Gupta and Gurudeep singh (2000). Seasonally PH showed maximum values during rainy and minimum during summer, similar observations have been made by Chetana Suvarna and Somashekar (1997) and the same has been attributed to increased decomposition rate leading to acidification. Electrical conductivity recorded maximum values during rainy and minimum values during winter. Patel and Patel (1993) arrived at similar conclusion, which is mainly due to soil erosion and high ionic concentration, which is also substantiated by the findings of Bharti and Krishnamurthy (1994). Total and dissolved solids recorded seasonal maxima during summer and their minimum values noticed during rainy and winter. Similar observations have also been made by Abbasi et.al. (2000) and the same is attributed to less inflow of water with high impurities.

Chemical parameter chloride in the present studies reached its peak during summer and reduces in its concentration towards winter, which is due to evaporation and reduced water inflow and the same is supported by the findings of Shukla et.al, (1992). Maximum and minimum values of sulphate observed during rainy and summer respectively is due to flushing of ions in to the reservoir from surface runoff during rainy season as was also observed by Qadri et.al, (1981). Calcium in the present investigation reached its highest peak during rainy and lowest during summer, which is vice versa in case of magnesium and the same is in agreement with Jain Praveen and Telang (1996). A seasonal maximum of total hardness is recorded during summer followed by winter and minimum values during rainy season due to dilution, where our results are in conformity with the findings of Abbasi et.al, (2000). Both DO and BOD in the present study recorded their maximum values during rainy and minimum values during winter. Higher value of DO during rainy season is due to increased number of phytoplankton which releases oxygen during photosynthesis. Chetana suvarna and Somashekar (1997) have also reported the same. Our observation regarding BOD is supported by the findings of Jain Praveen et.al, (1997) and Kataria et. al, (1995) 
Range with mean, standard deviation and standard error of bacteria is represented in table-3. Seasonal variations of bacteria has been appended in table-4 and expressed in terms of MPN of coli forms /100ml. Mathur and Ramanathan (1996) have reported that, Coli form group as an indicator of faecal contamination has limitations since some of them can multiply outside the human and animal gut. Raveendran et.al, (1990) is of the opinion that, all coli form bacteria are not faecal and do not signify pollution. Faecal coli forms indicating faecal pollution of water are characterised by the signs such as weak motility, non sporulating, gram negative aerobes. As evidenced by table 3 and 4 the faecal coli forms in the present investigation ranged between 110 and 9200 reaching their maxima during rainy due to inflow of water and minimum values during winter season. Verma and Paul (1996) reported that, the influx of fresh water carrying faecal matter in to the reservoir brought about maximum density of faecal coli forms, the same is in conformity with our findings. Sheo kumar and Leela sha (1996) have reported minimum value of faecal coli forms in winter and attributed the same to low water temperature and minimum rain fall which are unsuitable for the growth of bacteria.

Faecal streptococci in the present investigation ranged between 17 to $540 / 100 \mathrm{ml}$ (Table-3). Seasonally, winter recorded highest density and lowest being recorded during rainy (Table-4). Mishra and Rao (1967) estimated the relative numbers of coli forms and faecal streptococci and reported that, coli forms outnumbered faecal streptococci, which is also in conformity with the findings of present investigation. Physico-chemical parameters investigated lie within the permissible limits.

\section{Conclusion:-}

High value of MPN of coli forms exceeds safe limit indicating severe deterioration of water quality which rendered the water unfit for potability as such. It is concluded that, faecal coli form group stands on equal footing as an indicator of pollution with coli form group. Presence of faecal streptococci in association with faecal coli forms further confirms excremental pollution. As the water is bacteriologically polluted, the water can be used for drinking purposes only after conventional treatment followed by disinfection. It is suggested to go for afforestation in the catchment area to check erosion and silting. Use of biofertilizers and biopesticides is to be encouraged in order to avoid nutrient enrichment.

\section{References:-}

1. Abbasi, S.A., Naseem Abbasi, Sony,R. and Madhavan, K.2000. Studies on the water quality of river Kuttaidi, Kerala: Pollution and Biomonitoring of Indian Rivers ED. Trivedy, R. K. ADB Publishers, Jaipur, India.30-46.

2. Anon, 1982.The Bacteriological examination of Drinking water samples: Reports on public health and medical subjects No 71. Methods for the examination of Water and associated materials. PP:1-91.London:HMSO

3. APHA 2005. Standard methods for the examination of water and waste water $20^{\text {th }}$ edition. American Public Health Association. Washington DC.

4. Bharathi, S. G. and Krishnamurthy, S.R.1994. Water quality of the polluted River Kali near Dandeli (North Karnataka District) Karnataka. Indian. Envtl. Ecol.10 (4):864-868.

5. Chetana Suvarna, A. and Somashekar, R. K.1997. Ecological study on the Riverine Ecosystem of Karnataka11.Physico-chemical characterization of River Vrishabhavathi. J. Envtl. Poll.4 (1):71-77.

6. Gupta, B.K. and Gurudeep Singh.2000. Damodar River polluted due to coal washeries in pollution and Biomonitoring of Indian Rivers Ed.Trivedy, R.K. ABD Publishers, Jaipur, India. 47-69.

7. Jain Praveen and Ahamed Irfan.1997. Heavy metal contamination assessment of Kerwan dam water near Bhopal. Oriental. Jour. Chem.13 (1):93-94.

8. Jain Praveen. Telang Sanjay and Khan Jawad Ahamed. 1996. Microbiological and Physico-chemical aspects of Parbati river of Schore district (M.P). Oriental Jour. Chem. 12(3):131-315.

9. Kataria, H.C., Jain, O.P., Gupta, S.S., Shrivastava, R.M. and Shandilya, A.K. 1995. Physico-chemical analysis of water of Kubza river of Hoshangbad. Oriental Jour. Chem. 11(2):157-159.

10. Kolkwitz, R and Marsson, M. 1908. Okologie der pflanzlichen saprobien. Ber Deutsche Bot Ges. 26a:505-511 
11. Manjappa, S.2001.Heavy metal pollution in River Bhadra near Bhadravati Town, Karnataka. Ph.D thesis, Kuvempu University, Karnataka.

12. Mathur, R. P. and Ramanathan, K. N. 1966. Significance of Enterococci as Pollution indicator. Envtl. Health.VII:1-5.

13. Mishra, R. P. and Rao, N. U. 1967. Environmental Health.9:8

14. Parvateesan, M. and Sudha Gupta.1992. Physico-chemical characteristics of a lake receiving effluent from textile mills in Rajasthan. Poll. Res.13 (4):317-321.

15. Patel, M.K. and Patel, Tanoj Kumari. 1993. Assesment of water quality in the rivers of western Orissa: Part-1River Sankh. Indian J.Envtl.Prot.13 (2):909-916.

16. Qadri, M. Y., Showakat, A. N., Mustaffa, G. and Yousuf, A. R. 1981. Limnology of two trout streams of Kashmir. Jour. Indian. Inst. Sci. 63:137-141.

17. Raveendran, O., Gore, P.S., Iyer,T.S.G., Verma,P.R.G. AND Sankaranarayanan, V. N. 1990. Occurrence of enteric bacteria in Sea water and Mussels along the south west coast of India. Indian. Jour. Mar. Sci.19; 282-284.

18. Sheo Kumar, and Leela, C. Sha. 1996. Incidence of indicator bacteria in different drinking water sources: Assessment of water pollution Ed. Mishra, S. R. APH Publishing Corporation. New Delhi.

19. Shukla, S.C., Tripathi, B. D., Mishra, B.P and Chaturvedy, S .S.1992. Physico-chemical and bacteriological properties of the water of river Ganga at Ghazipur. Comp. Physiol.Ecol:17(3):92-96.

20. Vanaja, R.1998.Ecological studies on River Tungabhadra near Harihar. Ph.D thesis. Kuvempu University, Karnataka.

21. Verma, P. K. and Poul, D.K. 1996.Bacteriological water quality in a hill stream of Santhal Pargana, Bihar. Jour.Envt.Poll.3 (2):97-101.

22. WHO. 1998. World Health Organisation. Guidelines for Drinking Water Quality.Vol.2.WHO Geneva. 